\title{
Recent trends in HIV prevalence in a remote setting of southern India: Insights into arranging HIV control policies
}

\author{
Ramalingam Sekar, Murugesan Amudhan, Moorthy Sivashankar, Manoharan Mythreyee \\ Department of Microbiology, Faculty of Medicine, Government Theni Medical College, The Tamilnadu Dr. MGR \\ Medical University, Theni, India
}

\begin{abstract}
Introduction: Constant vigilance of the dynamics of HIV prevalence is important in estimating, regulating, and implementing prevention programs. The objective of this study was to investigate the trend in the prevalence of HIV infection over six years among specific demographic groups in the remote district of southern India.

Methodology: All high-risk attendees of the Integrated Counseling and Testing Centre, Government Theni Medical College between April 2005 and December 2010 were included in this study. Characteristics including age, sex, place of residence, literacy, and HIV sero-status were collected as per the guidelines of the National AIDS Control Organization.

Results: A total of 50,043 data sets were analyzed; 3,282 (6.6\%) tested positive for HIV infection. The prevalence of HIV infection among the $\leq 25$ age group was significantly lower as compared to the elderly $(4.4 \%$ vs. $6.9 \%$; odds ratio $0.62 ; 95 \%$ confidence interval $0.55-0.71 ; \mathrm{p}$ $<0.01)$. There was a decline in HIV prevalence among both age groups $\left(\mathrm{P}_{\text {trend }}<0.01\right.$ for $\leq 25$ year-old; $-82.3 \%$ and $\mathrm{P}_{\text {trend }}<0.01$ for $>25$ year old, $-14.2 \%)$, males $\left(\mathrm{P}_{\text {trend }}<0.01 ;-50.9 \%\right)$, the urban population $\left(\mathrm{P}_{\text {trend }}<0.01 ;-45.9 \%\right)$, and illiterates $\left(\mathrm{P}_{\text {trend }}<0.01 ;-68 \%\right)$. The trend of HIV prevalence among females $\left(\mathrm{P}_{\text {trend }}=0.48 ;+9.1 \%\right)$, the rural population $\left(\mathrm{P}_{\text {trend }}=0.95 ;-7.1 \%\right)$, and literate population $\left(\mathrm{P}_{\text {trend }}=\right.$ $0.44 ;+28 \%$ ) was statistically insignificant.

Conclusion: HIV prevalence is stable in the female population, while it is decreasing in male population, indicating that current interventions must be strengthened to reduce HIV prevalence among females.
\end{abstract}

Key words: HIV; prevalence; epidemiology; declining trend

J Infect Dev Ctries 2013; 7(11):838-843. doi:10.3855/jidc.2907

(Received 01 August 2012 - Accepted 04 February 2013)

Copyright (C) 2013 Sekar et al. This is an open-access article distributed under the Creative Commons Attribution License, which permits unrestricted use, distribution, and reproduction in any medium, provided the original work is properly cited.

\section{Introduction}

The epidemiology of human immunodeficiency virus (HIV) infection in India has changed significantly since the early 1980s when it began as an epidemic predominantly among high-risk groups such as female sex workers and injecting drug users $[1,4]$. Today, HIV/acquired immune deficiency syndrome (AIDS) is a disease of far greater demographic diversity, affecting all ages, sexes, races, and income levels, involving multiple transmission risk behaviors. Hence, the HIV epidemic in India has moved more and more from urban to rural areas and from high-risk to general populations [1,3]. This epidemiologic diversity is important to understand in order to target the interventions needed for diagnosis and treatment and to potentially reduce virus transmission. India has a population of 1.1 billion people - one sixth of the world's population - and is currently home to 2.27 million people infected with HIV $[3,4]$.
The first case of HIV infection in India was reported in 1987 [5] from Tamil Nadu, a state in southern India. Since then, the seroprevalence of HIV in Tamil Nadu and elsewhere in India has increased steadily. The total number of HIV-infected individuals in the country was estimated at 5.1 million at the end of 2003, and 5.7 million in 2006 [6]. Interestingly, the number of HIV infections in India has been reported to be 2.3 million in 2008 by the National AIDS Control Organization (NACO) [3]. This large variation is to the result of an over-projection of HIV estimates to the national population based on the surveillance data of high-prevalence areas. A later report provided more reliable data since the surveillance sites were equally distributed throughout the nation. United Nations AIDS (UNAIDS) recently indicated a significant decline in the global HIV infection rate. One of the UN's Millennium Development Goals is the halting of HIV infection by 2015 [4,7]. A declining trend of HIV prevalence was also observed in Africa, which is home 
to the largest number of patients living with HIV/AIDS in the world [7]. Nevertheless, HIV remains an important cause of morbidity and mortality in India[7,8].

Since India is a highly populated country, and although the number of surveillance sites is expanding, the data on HIV prevalence may still be inadequate, as one percent variation in the projection would result in a significant variation in the actual number of cases $[6,9]$. Hence, it is necessary to investigate the prevalence of HIV infection in the local community to conceive and implement the necessary remedial programs $[10,11]$. Theni is one of the remote districts of Tamil Nadu, with a population size of about 1.1 million people [12]. Together, the states of Tamil Nadu and other south Indian states (Andhra Pradesh, Karnataka, and Maharashtra) account for $60 \%$ of HIV infections in India [3,4].

Recently, we have reported the prevalence of transfusion-transmissible infections in our region [13]. The present study aimed to investigate the risk of HIV infection among different population groups based on age, sex, residence, and literacy, and to identify the trend of HIV prevalence. This information could be useful for NACO to prioritize HIV prevention strategies and resource allocation [14].

\section{Methodology}

Setting

The current study was conducted in the Department of Microbiology, Government Theni Medical College, Theni District, Tamil Nadu state, a tertiary care referral hospital and a state reference laboratory for HIV/AIDS.

\section{Participants and period of study}

A retrospective analysis of data from the Integrated Counseling and Testing Centre (ICTC) attached to the tertiary care hospital was performed. The present study included data of all high-risk attendees between April 2005 and December 2010. Antenatal care participants of ICTC were excluded, since they were reflective of the general population. The patient population was categorized into two groups based on age, sex, place of residence, and literacy. Most of the ICTC attendees were recruited from Tamil Nadu state; a few from Kerala were recruited.

\section{Specimens}

Three $\mathrm{mL}$ of venous blood samples were collected in a sterile plain container and allowed to clot for 30 minutes at room temperature $\left(25-30^{\circ} \mathrm{C}\right)$. The serum sample was separated after centrifugation and stored in a properly labeled sterile screw-capped container [15].

Serology

HIV antibodies were tested by one screening test (ELISA/Rapid) and two supplemental tests (ELISA/Rapid) as per the standard guidelines (strategy/algorithm III) published by NACO [15].

\section{Statistical analysis}

Statistical analyses of data were performed with GraphPad Prism version 5.03 (GraphPad Software Inc., San Diego, USA) using the chi-square test for trend; the statistical significance was set at $\mathrm{p}<0.05$.

\section{Results}

During the study period of six years, a total of 50,043 participants were enrolled in the ICTC. A total of $22,768(45.5 \%)$ were males and $27,275(54.5 \%)$ were females; $6,411(12.8 \%)$ were 25 years of age or younger. Among them 3,282 (6.6\%) were found to be positive for HIV infection [16]. The yearly prevalence of HIV infection in this cohort was observed to be declining in concordance with national and global estimate $[3,4,7,17]$. The prevalence of HIV infection among the $\leq 25$ age group was found as $4.4 \%$, and its counterpart, the $>25$ age group, had an HIV prevalence of $6.9 \%$. Therefore, the prevalence of HIV infection was documented to be 1.56 fold lower in the $\leq 25$ age group when compared with the $>25$ age group $(4.4 \%$ vs. $6.9 \%$, respectively; odds ratio [OR] $0.62 ; 95 \%$ confidence interval [CI] $0.55-0.71 ; \mathrm{p}<$ 0.01 ) (Table 1). The analysis of the yearly prevalence of HIV infection revealed a declining trend among both study groups.

The prevalence of HIV infection among males was $8.9 \%$ and among females, $4.6 \%$ (OR 2.01; 95\% CI 1.87-2.16; $\mathrm{p}<0.01$ ) (Table 2). Although the male population showed a high risk of acquiring HIV infection, the yearly analysis of HIV prevalence revealed a declining trend among the male population.

Among the study participants, 30,332 (60.6\%) lived in a rural area. The prevalence of HIV infection among the people in rural and urban areas was similar $(5.6 \%)$. Therefore, the place of residence was identified as not having any association with HIV prevalence (Table 3). However, the yearly analysis of HIV prevalence revealed a declining trend among the urban population, and the prevalence remained stable among the rural population. 
Table 1: Age-based HIV prevalence among ICTC attendees in a remote area of southern India.

\begin{tabular}{|c|c|c|c|c|c|c|}
\hline \multirow[b]{2}{*}{ Year } & \multicolumn{2}{|c|}{ Age $\leq 25$ years } & \multicolumn{2}{|c|}{ Age $>25$ years } & \multirow[b]{2}{*}{$\begin{array}{c}\text { Odds Ratio (95\% } \\
\text { Confidence Interval) }\end{array}$} & \multirow[b]{2}{*}{ p Value } \\
\hline & $\begin{array}{c}\text { No. of } \\
\text { Samples } \\
\text { Tested }\end{array}$ & $\begin{array}{c}\text { No. of Samples } \\
\text { Positive for HIV } \\
(\%)\end{array}$ & $\begin{array}{c}\text { No. of } \\
\text { Samples } \\
\text { Tested }\end{array}$ & $\begin{array}{c}\text { No. of Samples } \\
\text { Positive for HIV } \\
(\%)\end{array}$ & & \\
\hline 2006 & 1061 & $64(6.03)$ & 8395 & $630(7.50)$ & $0.79(0.61$ to 1.03$)$ & 0.09 \\
\hline 2007 & 1369 & $57(4.16)$ & 8779 & $614(6.99)$ & $0.57(0.44$ to 0.76$)$ & $<0.01$ \\
\hline 2008 & 1379 & $61(4.42)$ & 8000 & $552(6.9)$ & $0.62(0.48$ to 0.82$)$ & $<0.01$ \\
\hline 2010 & 1281 & $28(2.19)$ & 7847 & $474(6.04)$ & $0.35(0.24$ to 0.51$)$ & $<0.01$ \\
\hline Total & 6411 & $282(4.40)$ & 43632 & $3000(6.88)$ & $0.62(0.55$ to 0.71$)$ & $<0.01$ \\
\hline
\end{tabular}

Table 2: Sex-based HIV prevalence among ICTC attendees in a remote area of southern India.

\begin{tabular}{|c|c|c|c|c|c|c|}
\hline Year & \multicolumn{2}{|c|}{ Male } & \multicolumn{2}{|c|}{ Female } & $\begin{array}{c}\text { Odds Ratio (95\% Confidence } \\
\text { Interval) }\end{array}$ & p Value \\
\hline 2006 & 3728 & $416(11.16)$ & 5728 & $278(4.85)$ & $2.46(2.10$ to 2.88$)$ & $<0.01$ \\
\hline 2007 & 4714 & $395(8.38)$ & 5434 & $276(5.08)$ & $1.71(1.46$ to 2$)$ & $<0.01$ \\
\hline 2008 & 4848 & $393(8.11)$ & 4531 & $220(4.86)$ & $1.73(1.46$ to 2.05$)$ & $<0.01$ \\
\hline Total & 22768 & 2022 (8.88) & 27275 & $1260(4.62)$ & $2.01(1.87$ to 2.16$)$ & $<0.01$ \\
\hline
\end{tabular}

Table 3: Residence-based HIV prevalence among ICTC attendees in a remote area of southern India.

\begin{tabular}{|c|c|c|c|c|c|c|}
\hline \multirow[b]{2}{*}{ Year } & \multicolumn{2}{|c|}{ Rural residents } & \multicolumn{2}{|c|}{ Urban residents } & \multirow[b]{2}{*}{$\begin{array}{c}\text { Odds Ratio (95\% Confidence } \\
\text { Interval) }\end{array}$} & \multirow[b]{2}{*}{ p Value } \\
\hline & $\begin{array}{c}\text { No. of } \\
\text { Samples } \\
\text { Tested } \\
\end{array}$ & $\begin{array}{l}\text { No. of Samples } \\
\text { Positive for HIV } \\
(\%)\end{array}$ & $\begin{array}{c}\text { No. of } \\
\text { Samples } \\
\text { Tested } \\
\end{array}$ & $\begin{array}{c}\text { No. of Samples } \\
\text { Positive for HIV } \\
(\%)\end{array}$ & & \\
\hline 2006 & 5996 & $400(6.67)$ & 3460 & $294(8.50)$ & $0.77(0.66$ to 0.90$)$ & $<0.01$ \\
\hline 2007 & 6470 & $386(5.97)$ & 3678 & $285(7.75)$ & $0.76(0.64$ to 0.89$)$ & $<0.01$ \\
\hline 2008 & 5418 & $337(6.22)$ & 3961 & $276(6.97)$ & $0.89(0.75$ to 1.04$)$ & 0.16 \\
\hline Total & 30322 & $1988(6.56)$ & 19721 & $1294(6.56)$ & $1.00(0.93$ to 1.07$)$ & 0.99 \\
\hline
\end{tabular}

Table 4: Literacy-based HIV prevalence among ICTC attendees in a remote area of southern India.

\begin{tabular}{|c|c|c|c|c|c|c|}
\hline \multirow[b]{2}{*}{ Year } & \multicolumn{2}{|c|}{ Illiterate } & \multicolumn{2}{|c|}{ Literate } & \multirow[b]{2}{*}{$\begin{array}{c}\text { Odds Ratio (95\% Confidence } \\
\text { Interval) }\end{array}$} & \multirow[b]{2}{*}{ p Value } \\
\hline & $\begin{array}{c}\text { No. of } \\
\text { Samples } \\
\text { Tested } \\
\end{array}$ & $\begin{array}{c}\text { No. of Samples } \\
\text { Positive for HIV } \\
(\%)\end{array}$ & $\begin{array}{c}\text { No. of } \\
\text { Samples } \\
\text { Tested } \\
\end{array}$ & $\begin{array}{c}\text { No. of Samples } \\
\text { Positive for HIV } \\
(\%)\end{array}$ & & \\
\hline 2006 & 6451 & $486(7.53)$ & 3005 & $208(6.92)$ & $1.10(0.93$ to 1.30$)$ & 0.31 \\
\hline 2007 & 6843 & $401(5.86)$ & 3305 & $270(8.17)$ & $0.70(0.60$ to 0.82$)$ & $<0.01$ \\
\hline 2008 & 6010 & $439(7.30)$ & 3369 & $174(5.16)$ & $1.45(1.21$ to 1.73$)$ & $<0.01$ \\
\hline Total & 29837 & $2195(7.36)$ & 20206 & $1087(5.38)$ & $1.40(1.30$ to 1.51$)$ & $<0.01$ \\
\hline
\end{tabular}


A total of 29,837 (59.6\%) patients were illiterate. The prevalence of HIV infection among the illiterate study group was significantly higher $(7.36 \%$ vs. $5.38 \%$, respectively; OR 1.40 ; 95\% CI $1.30-1.51$; $\mathrm{p}<$ 0.01) (Table 4). Although the illiterate population showed a high risk of acquiring HIV infection, the yearly analysis of HIV prevalence revealed a declining trend; nevertheless, the prevalence remained stable among the literate population.

Trend analysis revealed a declining trend of HIV prevalence among both age groups $\left(\mathrm{P}_{\text {trend }}<0.01\right.$ for age group $\leq 25$ and $\mathrm{P}_{\text {trend }}<0.01$ for age group $>25$ ), males $\left(\mathrm{P}_{\text {trend }}<0.01\right)$, the urban population $\left(\mathrm{P}_{\text {trend }}<\right.$ $0.01)$, and illiterates $\left(\mathrm{P}_{\text {trend }}<0.01\right)$. The trend of HIV prevalence among females $\left(\mathrm{P}_{\text {trend }}=0.48\right)$, the rural population $\left(\mathrm{P}_{\text {trend }}=0.95\right)$, and literates $\left(\mathrm{P}_{\text {trend }}=0.44\right)$ was statistically insignificant. Additionally, the overall analysis revealed that rural residence did not have any association with HIV prevalence when compared with urban residence.

\section{Discussion}

The results of this study demonstrate a significant decrease in HIV prevalence among the regional population between 2005 and 2010. This decrease mainly owed to a substantial decrease of HIV prevalence among individuals 25 years of age or younger, illiterates, and males.

The reduced HIV prevalence among the $\leq 25$ age group during the study could be because of the intense health education and awareness campaign about HIV/AIDS among all adolescents at India's schools and colleges in addition to the effective prevention of mother-to-child transmission of HIV [3]. The relative reduction in the $>25$ years age group was insignificant $(<33 \%)$. This observation could be because of the higher prevalence of HIV infection in older people, who do not have adequate awareness of HIV/AIDS and do not use condoms regularly [18]. The present study results corroborate national and global projections of HIV prevalence based on different age groups $[3,7]$. The adult HIV prevalence at the national level shows a steady decline from an estimated level of $0.45 \%$ in $2002,0.36 \%$ in 2006 , and $0.29 \%$ in 2008 . All the high-prevalence states show a clear declining trend in adult HIV prevalence [3].

Recent estimates on the proportion of HIV infection among males (61\%) and females (39\%) [19] were similar to the rates found in the current study $62 \%$ and $38 \%$, respectively. According to a previously published report, the odds of HIV infection among males were 2.27 times higher than for females [20]; the current study showed that the odds of HIV infection were two times higher for males. Notably, the prevalence of HIV infection was constantly high among the male population [3,7]; however, the yearly analysis revealed a declining trend of HIV prevalence during the study period, which indicates that the current strategies helped to reduce the prevalence in the male population.

Intriguingly, among all the study groups analyzed, HIV prevalence was found to be stable in the female population, while other study groups revealed a decreasing HIV prevalence. The national adult prevalence was $0.26 \%$ among women and $0.38 \%$ among men in 2008, and $0.25 \%$ among women and $0.36 \%$ among men in 2009 [3]. There are several factors that can increase women's vulnerability to HIV infection, including early marriage, illiteracy, ignorance about risk factors, and gender inequalities, along with biological factors. As a consequence, many women are extremely vulnerable to HIV infection even though they do not practice high-risk behavior. Reportedly, there has been an increase in HIV infection among females in the recent past $[1,21]$. Notably, significant proportions of new infections are reported from monogamous women in stable marital relationships, which indicates that marriage itself is a risk [6]. The results of the present study indicate that the current intervention programs must be specifically strengthened to control HIV prevalence among women.

The present study revealed there is no relationship between HIV infection and place of residence; however, it was one of the important risk factors in early years, which might be overcome by effective campaigns and awareness programs.

In contrast to these data, previous studies involving rural populations from southern India and other developing parts of the world reported an increased or higher HIV prevalence [17,22,23]. A report from NACO and other recent studies have shown an increased susceptibility and vulnerability to HIV infection among rural communities, signaling a potential for a further escalating epidemic $[1,3,23,27]$.

According to a UNAIDS report published in 2002, condom use among rural men was low [2]. In contrast, the scenario of HIV prevalence in Tamil Nadu [10,19] is greater in the urban population than in the rural population. On the other hand, the current study indicated that the place of residence does not have any impact on HIV prevalence. A similar observation was previously reported by Kumar et al. [22]. 
According to UNESCO [28], illiterates were highly vulnerable to HIV infection because of their lack of knowledge and engagement in unprotected sex. HIV prevalence was observed to be high among the illiterate population in early years; following the implementation of effective awareness programs, there was equilibrium and alternating peaks of HIV prevalence among the study populations. However, in 2010 , HIV prevalence was observed to be $6.72 \%$ vs. $3.68 \%$ (OR 1.89, 95\% CI 1.54 to 2.31 ). The prevalence rate must be monitored in the forthcoming years to determine the precise trend. The present study's results corroborated results from a recent report [22], in which the prevalence of HIV infection was higher in illiterates.

During early years of the study (2005), immediately after the initiation of ICTC (at the time VCTC - Voluntary Counseling and Testing Centre) in a remote setting of South India, participants were recruited based on voluntary participation. Notably, most of the attendees were reported to have multiple unprotected promiscuous sex exposures and were at extreme risk for sexually transmissible infection (STI). Conversely, the low-risk participants ignored the test due to stigma. Additionally, physicians often referred participants with clinical symptoms of HIV/AIDS in that period. During the later years (2007), the number of ICTC attendees increased, owing to the public awareness created by different media; also, the integration of the Revised National Tuberculosis Control Program (RNTCP) and STI clinic with ICTC increased the number of physician-referred participants. These factors might have contributed to a bias in patient selection during early years, being responsible for the higher prevalence of HIV in 2005. Another limitation of this study was not performing multiple logistic regression analysis for different variables analyzed. In univariate analysis, the influence of one variable on another variable is inevitable. The influence of other variables on rural residence might have prejudiced the insignificant association of rural residence with HIV infection - a contrasting statement from the existing literature. Additionally, this study excluded antenatal care participants of ICTC because it was reflective of the general population and might dilute the study participants and significantly decrease the prevalence of HIV among the high-risk group.

HIV testing, early diagnosis, and access to treatment are key strategies for HIV/AIDS prevention. Individuals unaware of their infection status are at high risk of transmitting infection to others [29], and of the progression of the disease since they cannot benefit from treatment. There is growing evidence that widespread access to treatment may reduce HIV prevalence by reducing viral load at the population level $[30,31]$. In addition, a meta-analysis showed that people diagnosed early are less likely to transmit the virus [32].

\section{Conclusion}

The trend of HIV prevalence among the population of a remote area in the southern Indian state of Tamil Nadu was found to be declining irrespective of age, residence, and literacy, indicating the effectiveness of NACP - III interventional programs. The stable HIV prevalence in the female population and the decrease in the male population indicates that the present interventions must be strengthened to control HIV prevalence with a special focus on females.

\section{References}

1. NACO (2006) National AIDS Control Programme Phase III (2006 - 2011). National AIDS Control Organisation Available:

http://www.nacoonline.org/upload/Publication/Strategy\%20a nd\%20Implementation $\% 20$ Plan $\% 20$ -

\%20NACO $\% 20$ Programme\%20Phase $\% 20 I I I \% 20 \% 282006$ 2011\%29\%202006.pdf. Accessed 06 October 2012.

2. UNAIDS (2002) Report on the global HIV/AIDS epidemic. Joint United Nations Programme on HIV/AIDS Available: http://data.unaids.org/pub/Report/2002/brglobal_aids_report_ en pdf red en.pdf. Accessed 06 October 2012.

3. NACO (2010) Annual Report - NACO 2009 -10. National AIDS Control Organisation Available: http://www.nacoonline.org/upload/AR\%202009-

10/NACO_AR_English\%20corrected.pdf. Accessed 06 October 2012.

4. UNAIDS (2010) India - Country Progress Report, 2010. Joint United Nations Programme on HIV/AIDS Available: http://data.unaids.org/pub/Report/2010/india_2010_country_p rogress_report_en.pdf. Accessed 06 October 2012.

5. Simoes EA, Babu PG, John TJ, Nirmala S, Solomon S, Lakshminarayana CS, Quinn TC (1987) Evidence for HTLVIII infection in prostitutes in Tamil Nadu (India). Indian J Med Res 85: 335-338.

6. Steinbrook R (2007) HIV in India--a complex epidemic. N Engl J Med 356: 1089-1093.

7. UNAIDS (2010) Report on the Global AIDS Epidemic. Joint United Nations Programme on HIV/AIDS Available: http://www.unaids.org/en/media/unaids/contentassets/docume nts/unaidspublication/2010/20101123_globalreport_en.pdf. Accessed 06 October 2012.

8. Jha P, Kumar R, Khera A, Bhattacharya M, Arora P, Gajalakshmi V, Bhatia P, Kam D, Bassani DG, Sullivan A, Suraweera W, McLaughlin C, Dhingra N, Nagelkerke N (2010) HIV mortality and infection in India: estimates from nationally representative mortality survey of 1.1 million homes. BMJ 340: c621. 
9. Vyas N, Hooja S, Sinha P, Mathur A, Singhal A, Vyas L (2009) Prevalence of HIV/AIDS and Prediction of Future Trends in North-west Region of India: A six-year ICTC-based Study. Indian J Community Med 34: 212-217.

10. Dandona L, Lakshmi V, Sudha T, Kumar GA, Dandona R (2006) A population-based study of human immunodeficiency virus in south India reveals major differences from sentinel surveillance-based estimates. BMC Med 4: 31

11. Dandona R, Kumar SG, Kumar GA, Lakshmi V, Dandona L (2009) HIV testing among adults in a high prevalence district in India. Natl Med J India 22: 289-293.

12. GTN (2010) District at a Glance - Theni. Government of Tamil Nadu Available: http://www.theni.tn.nic.in/pdfs/District $\% 20$ at $\% 20 a \% 20$ Glanc e.pdf. Accessed 06 October 2012.

13. Mythreyee M, Jayachandran C, Amudhan M, Sivashankar M, Mythily N, Sekar R (2011) Low prevalence of transfusiontransmissible infections among voluntary blood donors in South India. J Infect Dev Ctries 5: 410-412.

14. Fiamma A, Lissouba P, Amy OE, Singh B, Laeyendecker O, Quinn TC, Taljaard D, Auvert B (2010) Can HIV incidence testing be used for evaluating HIV intervention programs? A reanalysis of the Orange Farm male circumcision trial (ANRS-1265). BMC Infect Dis 10: 137.

15. NACO (2007) Guidelines on HIV Testing. National AIDS Control Organisation Available: http://www.nacoonline.org/upload/Final\%20Publications/Blo od\%20Safety/GUILDELINES\%20FOR\%20HIV\%20TESTIN G.pdf. Accessed 06 October 2012.

16. Sekar R, Amudhan M, Sivashankar M, Veeran R, Jayachandran C, Mythreyee M (2011) Declining trend of HIV infection among the rural population of South India - a comparison of HIV prevalence in high risk and low risk groups. J Infect 63: 91-92.

17. Arora P, Kumar R, Bhattacharya M, Nagelkerke NJ, Jha P (2008) Trends in HIV incidence in India from 2000 to 2007. Lancet 372: 289-290.

18. Benjamin AI, Singh S, Sengupta P, Dhanoa J (2007) HIV sero-prevalence and knowledge, behaviour and practices regarding HIV/AIDS in specific population groups in Ludhiana, Punjab. Indian J Public Health 51: 33-38.

19. NACO (2008) HIV Sentinel Surveillance and HIV Estimation, 2006. National AIDS Control Organisation Available:

http://www.nacoonline.org/upload/NACO $\% 20 \mathrm{PDF} /$ Note $\% 20$ on $\% 20$ HIV $\% 20$ Sentinel $\% 20$ Surveillance $\% 20$ and $\% 20$ HIV $\% 2$ 0Estimation_01\%20Feb\%2008.pdf. Accessed 06 October 2012.

20. Das BR, Khadapkar R, Giganti M, Sahni S, Shankarappa R (2006) Age, sex, and HIV seroprevalence among individuals from different parts of India tested for HIV infection in a nongovernmental setting. AIDS Res Hum Retroviruses 22: 1067-1073.

21. Joseph S, Kielmann K, Kudale A, Sheikh K, Shinde S, Porter J, Rangan S (2010) Examining sex differentials in the uptake and process of HIV testing in three high prevalence districts of India. AIDS Care 22: 286-295.

22. Kumar R, Jha P, Arora P, Mony P, Bhatia P, Millson P, Dhingra N, Bhattacharya M, Remis RS, Nagelkerke N (2006)
Trends in HIV-1 in young adults in south India from 2000 to 2004: a prevalence study. Lancet 367: 1164-1172.

23. Wambura $M$, Urassa $M$, Isingo $R$, Ndege $M$, Marston $M$, Slaymaker E, Mngara J, Changalucha J, Boerma TJ, Zaba B (2007) HIV prevalence and incidence in rural Tanzania: results from 10 years of follow-up in an open-cohort study. J Acquir Immune Defic Syndr 46: 616-623.

24. Mmbaga EJ, Hussain A, Leyna GH, Holm-Hansen C, Mnyika KS, Sam NE, Klouman E, Klepp KI (2007) Trends in HIV-1 prevalence and risk behaviours over 15 years in a rural population in Kilimanjaro region of Tanzania. AIDS Res Ther 4: 23.

25. Barnighausen T, Tanser F, Newell ML (2009) Lack of a decline in HIV incidence in a rural community with high HIV prevalence in South Africa, 2003-2007. AIDS Res Hum Retroviruses 25: 405-409.

26. Becker ML, Ramesh BM, Washington RG, Halli S, Blanchard JF, Moses S (2007) Prevalence and determinants of HIV infection in South India: a heterogeneous, rural epidemic. AIDS 21: 739-747.

27. Sherr L, Lopman B, Kakowa M, Dube S, Chawira G, Nyamukapa C, Oberzaucher N, Cremin I, Gregson S (2007) Voluntary counselling and testing: uptake, impact on sexual behaviour, and HIV incidence in a rural Zimbabwean cohort. AIDS 21: 851-860.

28. UNESCO (2007) Making the connections: Why literacy matters for HIV prevention. United Nations Educational, Scientific and Cultural Organisation Available: unesdoc.unesco.org/images/0015/001541/154159e.pdf. Accessed 06 October 2012.

29. Sprenger M (2010) Know, treat, prevent--HIV testing, a key strategy in the prevention and control of the HIV/AIDS epidemic. Euro Surveill 15.

30. Montaner JS, Lima VD, Barrios R, Yip B, Wood E, Kerr T, Shannon K, Harrigan PR, Hogg RS, Daly P, Kendall P (2010) Association of highly active antiretroviral therapy coverage, population viral load, and yearly new HIV diagnoses in British Columbia, Canada: a population-based study. Lancet 376: 532-539.

31. De Cock KM, Gilks CF, Lo YR, Guerma T (2009) Can antiretroviral therapy eliminate HIV transmission? Lancet 373: 7-9.

32. Marks G, Crepaz N, Janssen RS (2006) Estimating sexual transmission of HIV from persons aware and unaware that they are infected with the virus in the USA. AIDS 20: 14471450 .

\section{Corresponding author}

Ramalingam Sekar

Department of Microbiology, Government Theni Medical College

The Tamilnadu Dr. MGR. Medical University

Theni 625512, India

Phone: +91 4546263704

Fax: +914546263696

E-mail: sekaralingam@gmail.com

Conflict of interests: No conflict of interests is declared. 